fournal of Medical Genetics (1972). 9, 324.

\title{
X-Linked Mental Retardation without Physical Abnormality (Renpenning's Syndrome) in Sibs in an Institution
}

\author{
GILLIAN TURNER, BERT ENGISCH, DAVID G. LINDSAY, and BRIAN TURNER \\ Children's Medical Research Foundation, Royal Alexandra Hospital for Children and Peat and Milson Island \\ Hospital, Sydney, Australia
}

A number of families have been reported in which mental retardation appeared to be segregating as an X-linked recessive (Martin and Bell, 1943; Allan, Herndon, and Dudley, 1944; Losowsky, 1961 ; Renpenning et al, 1962; Dunn et al, 1962/1963; Neuhäuser et al, 1969; Snyder and Robinson, 1969; Neuhäuser and Zerbin-Rüdin, 1970). We reported 5 such families (Turner, Turner, and Collins, 1971b) in which the moderately retarded males were distinguished by the fact that they showed no physical abnormality. The first family in which X-linked mental retardation was associated with a similar lack of physical stigmata in the affected males was described by Renpenning et al (1962) and a similar family study was later published by Dunn et al $(1962 / 1963)$. On the basis of the observations that the affected males in these families showed no physical stigmata the histories of a group of moderately retarded males without physical stigmata were examined and it was found that $60 \%$ has either an affected brother or a family history compatible with an X-linked entity. It was proposed therefore that the absence of physical abnormality in a moderately retarded male was suggestive of an X-linked form of mental retardation and the eponym of Renpenning's syndrome was suggested (Turner et al, 1971b).

In order to obtain substantiation of this observation the brother pairs with mental retardation in an institution were ascertained and their families were studied.

\section{Method}

Peat and Milson Island Hospital of the New South Wales Department of Health, is an institution for the mentally retarded and has 488 male patients of whom the majority are moderately, severely, or profoundly retarded. All the patients who were known to have a

Received 21 February 1972. retarded male sib were selected for the study. Those who had been admitted as wards of the State were excluded as family study was not possible.

There were 18 affected brother pairs included in the study. The ages of these patients ranged from the late teens to the 50s; all had been admitted because of mental retardation-the majority while in their early teens. The medical histories of these individuals before admission was minimal and in most cases contact with the family had lapsed. A letter was written to the address of the nearest relative requesting an interview, or, if the family lived in the country, a letter was written to the local general practitioner in the area requesting details about the family. The response to this initial attempt to contact the families was poor. The last known address was therefore visited and this proved more fruitful. Once contact was established with any member of the family they were most helpful and interested. It was then possible to contact other branches of the family and to confirm details of the family history. The affected male relatives were examined wherever possible and details were confirmed from other agencies.

All the male members of the 18 sibships were physically examined. In all the sibships the mental retardation was of the same degree, and in all pairs the physical features or lack of them was very similar. Urine was tested for aminoaciduria and for excess mucopolysaccharide.

Lack of physical abnormality was defined by the following criteria: (1) Height below the 97th centile or above the 3rd centile. (2) Head circumference below the 97th centile or above the 3 rd centile. (3) No fits, or occasional fits not requiring treatment. (4) No major, and no more than 2 minor congenital abnormalities. (5) No definite diagnosis. (6) The absence of definite neurological signs.

\section{Results}

Medical examination of the 18 sibships showed that in 11 of them both affected brothers showed the lack of physical stigmata as defined above. In 9 of 
these 11 families relatives were available for interview and in 7 there was found to be a similarly affected male on the distaff side of the family. In all, 17 affected male relatives were identified whereas only 2 affected females were found. In none of the families was there a history of mental retardation in

\section{TABLE I}

\begin{tabular}{lr}
\hline Total no. of sibships & 18 \\
Total no. with clinical features of & 11 \\
$\begin{array}{l}\text { Renpenning's syndrome } \\
\text { No. in which a family history was obtained }\end{array}$ & 9 \\
$\begin{array}{l}\text { No. with a similarly affected male in the } \\
\text { maternal family history }\end{array}$ & 7 \\
\hline
\end{tabular}

TABLE II

FAMILY HISTORY OF SIBSHIPS WITHOUT PHYSICAL ABNORMALITY

\begin{tabular}{|c|c|c|}
\hline Sibship & Relative Contacted & $\begin{array}{l}\text { Mentally Retarded Relatives } \\
\text { On Maternal Side of Family }\end{array}$ \\
\hline $\begin{array}{r}1 \\
2 \\
4 \\
6 \\
8 \\
10 \\
11\end{array}$ & $\begin{array}{l}\text { Yes } \\
\text { Yes } \\
\text { No } \\
\text { No } \\
\text { Yes } \\
\text { Yes } \\
\text { Yes (family history incom- }\end{array}$ & $\begin{array}{l}1 \text { great uncle } \\
1 \text { half brother; } 1 \text { uncle } \\
1 \text { sister } \\
1 \text { male cousin; } 2 \text { nephews } \\
\text { No affected relatives } \\
\text { No affected relatives }\end{array}$ \\
\hline $\begin{array}{l}13 \\
14\end{array}$ & $\begin{array}{l}\text { plete) } \\
\text { Yes } \\
\text { Yes }\end{array}$ & $\begin{array}{l}1 \text { male cousin } \\
1 \text { uncle; } 6 \text { nephews; } 1 \text { great } \\
\text { nephew }\end{array}$ \\
\hline $\begin{array}{l}16 \\
18\end{array}$ & $\begin{array}{l}\text { Yes } \\
\text { Yes (family history incom- } \\
\text { plete) }\end{array}$ & $\begin{array}{l}1 \text { nephew } \\
1 \text { male cousin; } 1 \text { female } \\
\text { cousin }\end{array}$ \\
\hline
\end{tabular}

the paternal relatives apart from one infant with Down's syndrome. The clinical details and some pedigrees of the families are given in the Appendix (pp. 326-330). A summary of the affected relatives of the 11 sibships without physical stigmata are given in Tables I and II. A summary of the clinical findings in the 7 sibships with physical abnormalities is given in Table III.

\section{Discussion}

This study of 18 male sibships in an institution shows that over half of the pairs had no physical abnormality and that in this group the majority have a family history compatible with an X-linked entity. There were 2 affected female relatives as against 17 affected male relatives on the maternal side of the family. In sibship 4 there was a mildly retarded sister and in sibship 18 a female cousin with profound mental retardation associated with microcephaly and spasticity. No mentally retarded relatives, relevant to the present study, were found in the paternal relatives.

Renpenning's syndrome appears to be an Xlinked, rather than an X-limited, abnormality as there is a known 45, X individual in an affected family who is severely mentally retarded (Turner et al, 1971b). None of the affected males have been known to reproduce, presumably by virtue of their degree of retardation, so there has been no

TABLE III

DETAILS OF SIBSHIPS WITH PHYSICAL ABNORMALITY

\begin{tabular}{|c|c|c|c|c|c|}
\hline $\begin{array}{c}\text { Sibship } \\
\text { No. }\end{array}$ & No. Affected & $\begin{array}{c}\text { Clinical Features of Affected } \\
\text { Members }\end{array}$ & $\begin{array}{l}\text { Relative(s) } \\
\text { Contacted }\end{array}$ & Family History & Diagnosis \\
\hline 3 & 2 brothers & $\begin{array}{l}\text { Both profoundly retarded with } \\
\text { poor muscle development }\end{array}$ & Sister & $\begin{array}{l}\text { No consanguinity; no known } \\
\text { retarded relative }\end{array}$ & Not known \\
\hline 5 & 2 brothers & $\begin{array}{l}\text { Both moderately retarded with no } \\
\text { physical abnormality }\end{array}$ & $\begin{array}{l}\text { Whereabouts } \\
\text { unknown }\end{array}$ & & Phenylketonuria \\
\hline 7 & 2 brothers & $\begin{array}{l}\text { Both profoundly retarded with } \\
\text { mild spastic diplegia; failure of } \\
\text { secondary sex development in } \\
\text { one brother aged } 20\end{array}$ & Parents & $\begin{array}{l}\text { No consanguinity; no known } \\
\text { retarded relative }\end{array}$ & Not known \\
\hline 9 & 2 brothers & $\begin{array}{l}\text { Both head circumferences below } \\
3 \text { rd centile; height } 139 \mathrm{~cm} \text { and } \\
157 \mathrm{~cm} \text {; both with spastic } \\
\text { diplegia; one brother heart } \\
\text { murmur-ventricular septal } \\
\text { defect? }\end{array}$ & $\begin{array}{l}\text { Whereabouts } \\
\text { unknown }\end{array}$ & & $\begin{array}{l}\text { Clinical features } \\
\text { suggestive of } \\
\text { maternal phenyl- } \\
\text { ketonuria }\end{array}$ \\
\hline 12 & 2 brothers & Both with epileptic fits & $\begin{array}{l}\text { Sister and } \\
\text { parents }\end{array}$ & $\begin{array}{l}\text { No consanguinity; no known } \\
\text { retarded relative; both } \\
\text { parents deaf and dumb }\end{array}$ & $\begin{array}{l}\text { Degenerative } \\
\text { disease? }\end{array}$ \\
\hline 15 & $\begin{array}{l}2 \text { brothers; } \\
1 \text { maternal } \\
\text { half-brother }\end{array}$ & $\begin{array}{l}\text { All } 3 \text { moderately retarded with } \\
\text { spasticity mainly affecting upper } \\
\text { limbs and dystonia }\end{array}$ & $\begin{array}{l}\text { Whereabouts } \\
\text { unknown }\end{array}$ & & $\begin{array}{l}\text { Variant of an } \\
\mathrm{X} \text {-linked form of } \\
\text { spastic diplegia? }\end{array}$ \\
\hline 17 & 2 brothers & & & $\begin{array}{l}\text { Extensive family history with } \\
\text { retarded relatives with low } \\
\text { birth weight and dwarfism } \\
\text { previously reported by Dey, } \\
\text { (1967) }\end{array}$ & \\
\hline
\end{tabular}


possibility of distinguishing between an X-limited entity and an X-linked entity by this method.

We had considered that there was no evidence of heterozygous expression but having talked with many more relatives, both obligatory carriers and those who appear not to be carriers, it does seem that in some families the carrier female is mentally slower than her presumptive non-carrier sisters. This appears to be the case in sibships 8,16 , and 18 . Attempts to organize psychological testing in these families was unsuccessful. The lower intelligence of the female carrier was also pointed out in the families described by Neuhäuser et al (1969). This may prove to be an aid to carrier detection in some families. The affected males in 2 sibships, nos. 4 and 6 , had testicular enlargement and a feminine body habitus. Description of the endocrinological investigation of these patients is in preparation.

Genetic counselling in these families is obviously very important. A family with a moderately retarded boy with no physical abnormality with a similarly affected male relative on the maternal side must be assumed to have an $\mathrm{X}$-linked disease, the mother being a carrier and the female relatives running the risk of being carriers. The family with a son with the features of Renpenning's syndrome but without positive family history is more difficult as there is, as yet, no objective method of confirming the diagnosis and no means of carrier detection. In this situation the recurrence risk figure we have been using is the empiric risk rate of 1:11 found from studying a group of moderately retarded males (Turner, Collins, and Turner, 1971a).

In this small, but selected, population it is of interest that there were 11 pairs of sibs with presumptive Renpenning's syndrome as against a single pair with phenylketonuria. It is probable that Renpenning's syndrome represents the most common cause of moderate mental retardation in males excluding Down's syndrome. The failure of this entity to be widely recognized appears to stem from the lack of distinguishing features and also, in part, because many of these families fall into a group which has been loosely labelled 'cultural-familial' retardation. Renpenning's syndrome appears to account for the male preponderence in the mentally retarded sibships and may well contribute significantly to the overall excess of males among the moderately mentally retarded. When the basic defect in Renpenning's syndrome is elucidated it may be found that this does not represent a single entity but at present it proves a useful concept for delineating a group of individuals in whom mental retardation is inherited by a locus on the $\mathrm{X}$ chromosome.

\section{Summary}

The family histories and physical features of $a \stackrel{\mathbb{D}}{\mathbb{D}}$

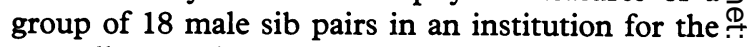
mentally retarded were studied. Eleven of the $18 \vec{\Rightarrow}$ pairs showed no physical abnormality. Family study was possible in 9 of these families and in 7 a similarly affected maternally related male was found $\overline{\bar{c}}$. further substantiating the X-linked nature of this $\frac{\mathrm{N}}{\mathrm{D}}$ entity. It is suggested that Renpenning's syndrome $\stackrel{\mathbb{D}}{\circ}$ or X-linked mental retardation without physical $\approx$ stigmata accounts for the male preponderance in $\vec{\circ}$ mentally retarded sibships in institutions and in $\overrightarrow{\vec{H}}$ part for the preponderance of males amongst the $\vec{\omega}$ moderately mentally retarded.

\section{REFERENCES}

Allan, W., Herndon, C. N., and Dudley, F. C. (1944). Some examples of the inheritance of mental deficiency: apparently sex $N$ linked idiocy and microcephaly. American fournal of Mental Deficiency, 48, 325-334.

Dey, J. (1967). Familial mental retardation associated with low birth weight dwarfism. In Proceedings of the 1st Congress of the International Association for the Scientific Study of Mental De- (D) ficiency, pp. 390-396. Michael Jackson, Reigate, Surrey.

Dunn, H. G., Renpenning, H., Gerrard, J. W., Miller, J. R., Tabata, T., and Federoff, S. (1962/1963). Mental retardation as a sexlinked defect. American fournal of Mental Deficiency, 67, 827-848.

Losowsky, M. S. (1961). Hereditary mental defect showing the pattern of sex influence. Fournal of Mental Deficiency Research, $5, \vec{\theta}$ 60-62.

Martin, J. P. and Bell, J. (1943). A pedigree of mental defect show ing sex-linkage. Fournal of Neurology and Psychiatry, 6, 154-157

Neuhäuser, G. and Zerbin-Rüdin, E. (1970). Oligophrenia wit probable sex-linked recessive inheritance. German Medica Monthly, 15, 343-346.

Neuhäuser, G., Zerbin-Rüdin, E., Pfeiffer, B. A., and Klar, H. (1969). Beobachtungen zum Problem des geschlechtsgebundenrecessiven Schwachsinns. Archiv für Psychiatrie und Nervenkrankheiten, vereingt mit Zeitschrift für die gesamte Neurologie und Psychiatrie, 212, 207-224.

Renpenning, H., Gerrard, J. W., Zaleski, W. A., and Tabata, T. (1962). Familial sex-linked mental retardation. Canadian Medical Association fournal, 87, 954-956.

Snyder, R. D. and Robinson, A. (1969). Recessive sex-linked mental retardation in the absence of other recognisable abnormalities. Clinical Pediatrics, 8, 669-674.

Turner, G., Collins, E., and Turner, B. (1971a). Recurrence risk of mental retardations in sibs. Medical fournal of Australia, 1, 1165-1166.

Turner, G., Turner, B., and Collins, E. (1971b). X-linked mental retardation without physical abnormality. Renpenning's syndrome. Developmental Medicine and Child Neurology, 13, 71-78.

\section{Appendix}

\section{Sibship 1 (Fig. 1).}

The mother (III.4) and the father of the propositi were both interviewed though divorced. The mother was an intelligent woman with a good job. IV.5 was born in 1947 and admitted aged 8, and IV.6 was born in 1948 and admitted aged 10 . Both had delayed motor milestones. IV.5 had been hyperactive. Both attended a special day school for the mentally retarded before admission. A maternal uncle (II.5) was admitted to an institution because of mental retardation at the age of 10 and died at 


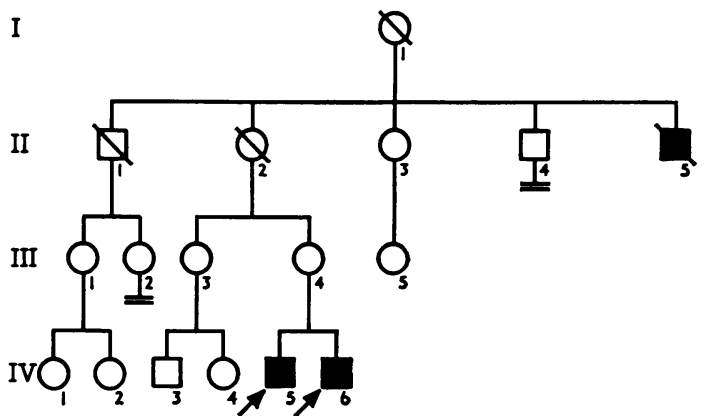

FIG. 1. Pedigree of sibship 1.

The pedigrees illustrated (Figs. 1-8) are of those sibships, where a family history could be obtained, whose members showed lack of physical abnormality. and $O=$ individuals with an IQ below 51 .

the Peat and Milson Island Hospital (PMH) at the age of 69 in 1939 . He was reported to have been of normal physical appearance.

\section{Sibship 2 (Fig. 2).}

The widow of a maternal uncle (II.2) was interviewed. She knew of the existence of only III.3 and III.4 at PMH. She knew that her husband had a brother (II.1) who had remained on a property with his parents but she had been told that he died from falling off a horse at the age of 25. The family were wealthy landowners and the husband of I.1 was the mayor for many years. Luckily one of the old nurses remembered the existence of an uncle of the propositi at PMH and his death certicate revealed the same next of kin and the same name as the alleged dead uncle. He died aged 63. There is no clinical description of him. III.2 was born in 1923 and admitted aged 33. His surname was his mother's maiden name and he was presumably therefore illegitimate; III. 3 born in 1938 and III.4 born in 1940 were admitted aged 11 and 9 , respectively.

These three males all have fine skin and no chest hair with little pubic hair; penile development was normal and testicular volume was $35 \mathrm{ml}$ (normal $25 \mathrm{ml}$ ).

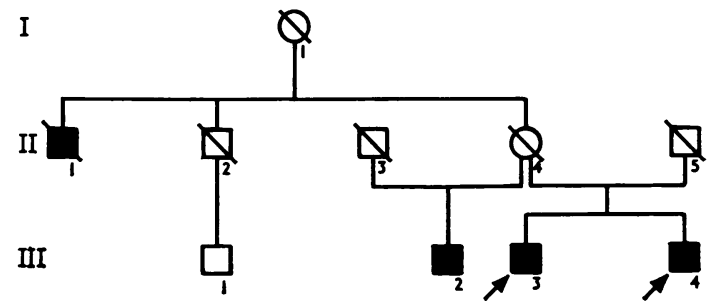

FIG. 2. Pedigree of sibship 2.

\section{Sibship 4}

The whereabouts of the relatives are unknown. One brother was born in 1925 and the other in 1928, and they were admitted at the ages of 15 and 12 . There is a sister in another institution; she was born in 1927 and admitted aged 14, pregnant. She has had 3 illegitimate pregnancies and at present is being courted by an expatient. She is mildly retarded and works in the hospital laundry, physical examination revealed no abnormalities. The parents were described as simple and there is said to be a normal married sister and 2 normal brothers.

\section{Sibship 6}

The whereabouts of the relatives are unknown. The 2 brothers were born in 1950 and 1951 and admitted at the ages of 11 and 12 . One has occasional prolonged fits and is severely retarded. Both have no chest hair, little pubic hair, normal penile development, and testicular volumes of $40 \mathrm{ml}$ (normal $25 \mathrm{ml}$ ). Both have heads which clinically look larger than normal but are $59 \mathrm{~cm}$ (between 90th and 97th centiles) in circumference.

\section{Sibship 8 (Fig. 3).}

The family history was originally obtained with the help of the general practioner who interviewed the mother (II.3). From the information obtained it was possible to interview II.7, III.4, III.8, III.18, and III.19. III. 5 was born in 1939 and admitted at the age of 6, and III.11 was born in 1950 and admitted at the age of 8 .

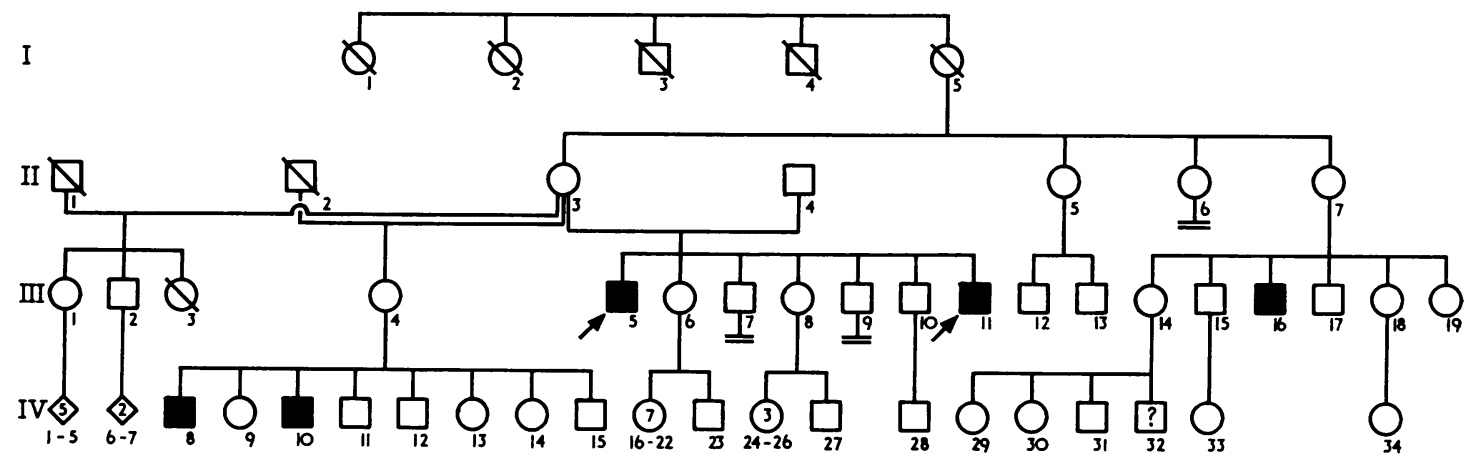

FIG. 3. Pedigree of sibship 8. 
A comparison of the intelligence of the 4 sisters in generation II was interesting; the 2 obligatory carriers (II.3 and II.7) were literate but simple in contrast to the description of their 2 sisters, one of whom (II.6) was a school teacher and the other (II.5) who married well and had a son who was a lawyer. III.4 was living in very poor circumstances with a husband on an invalid pension. She was able to write but was of limited intelligence. Her 2 affected sons (IV.8 and IV.10) were examined; they had no physical abnormalities and were attending a special school for the mentally retarded. The rest of the brothers and sisters in the family were not seen but were in the normal school stream although doing poorly and in trouble with the law. III.8 although living in poor circumstances was obviously much brighter than her sister II.4.

It was discovered that III.16 was a patient at PMH although it was not known before that he was related to the propositi. He is moderately retarded and has no physical abnormalities. III.14 is in England but it was stated that one of her sons (IV.32) aged 6 was having learning difficulties at school and had little speech. Again in this family there seemed to be differences in intelligence in the females. III.18 was a nurse but III.19, aged 18, was on a pension ostensibly because of shortening of one leg from poliomyelitis but was of borderline normal intelligence.

\section{Sibship 10 (Fig. 4).}

The father of the propositi, the husband of II.7 was interviewed. There was no family history of mental retardation. One brother (III.3) was born in 1950 and admitted to PMH aged 12. The other brother (III.5) was born in 1954 and admitted to another institution aged 16. Both had had delayed milestones and had attended special day schools for the mentally retarded before admission.

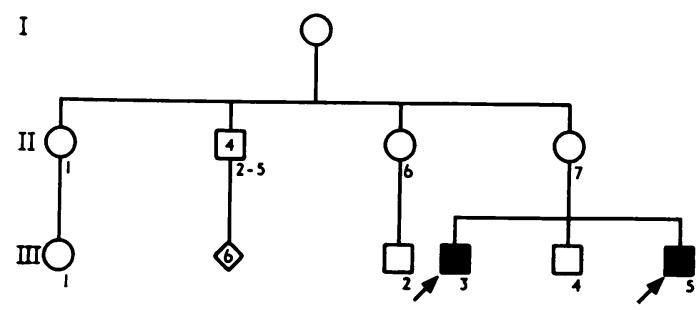

Fig. 4. Pedigree of sibship 10.

Sibship 11 (Fig. 5).

This family was seen originally by one of us (G.T.) in 1968 at a diagnostic clinic for the mentally retarded on the death of the mother of the propositi. At that time III.1, III.2, and III.3 had been admitted to PMH but III.8, III.9, and III.10 were at home and were being looked after chiefly by their 19-year-old sister (III.12). Institutional care was being requested fot these 3 retarded brothers. The history obtained at that time did not include any details about the relations of II.1 or of

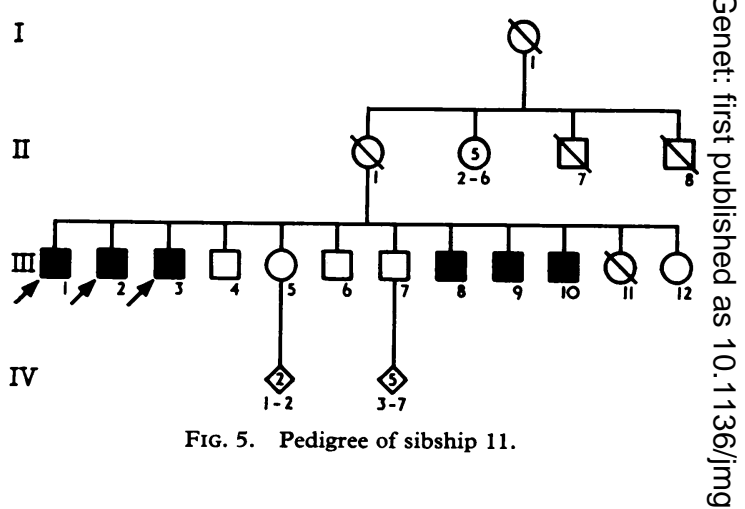

their offspring as there has been little contact with that 6 side of the family. On trying to re-establish contact with the family to complete this study, only III.4 could $N$ be traced and he was unwilling to be involved, so the family history is incomplete.

III.1 born 1926, admitted aged 17.

III. 2 born 1928, admitted aged 16 .

III.3 born 1929, admitted aged 15 . He has not been examined as he is now fostered by an ex staff member of PMH.

III. 8 born 1941, admitted aged 23 .

III. 9 born 1944, admitted aged 24 .

III.10 born 1945, admitted aged 23. None of these affected members had had any schooling as they had. been excluded after attending for a short time and thero were no facilities available for special schooling.

II.7 is said to have died in infancy and II.8 died in his teens, having been kicked by a horse.

\section{Sibship 13 (Fig. 6).}

The mother (III.6) and a sister (IV.7) of the propositi were interviewed. IV.11 was born in 1935 and admitted to hospital at the age of 17 . His older brother IV.8 born in 1931 had a period in another mental hospital at the age of 9 but his parents then took him home again. He cannot read or write and his speech is limited and indistinct. On physical examination he has no abnormalities. He assists his brother (IV.9) who is an electrician. IV.13 died at the age of 3 of meningitis but was recognized as being slow, having delayed milestones and no speech. IV.3 is known to be retarded and has been seen as an outpatient at a psychiatric hospital; he is 39 and lives and works on his family's property. He has not been examined but is reported to be of normal physical appearance.

\section{Sibship 14}

The pedigree of these two brothers has already been published (Turner $e t a l, 1971 \mathrm{~b}$ ) as it was the family which originally stimulated our interest in X-linked mental retardation. The brothers were born in 1926 and 1927 


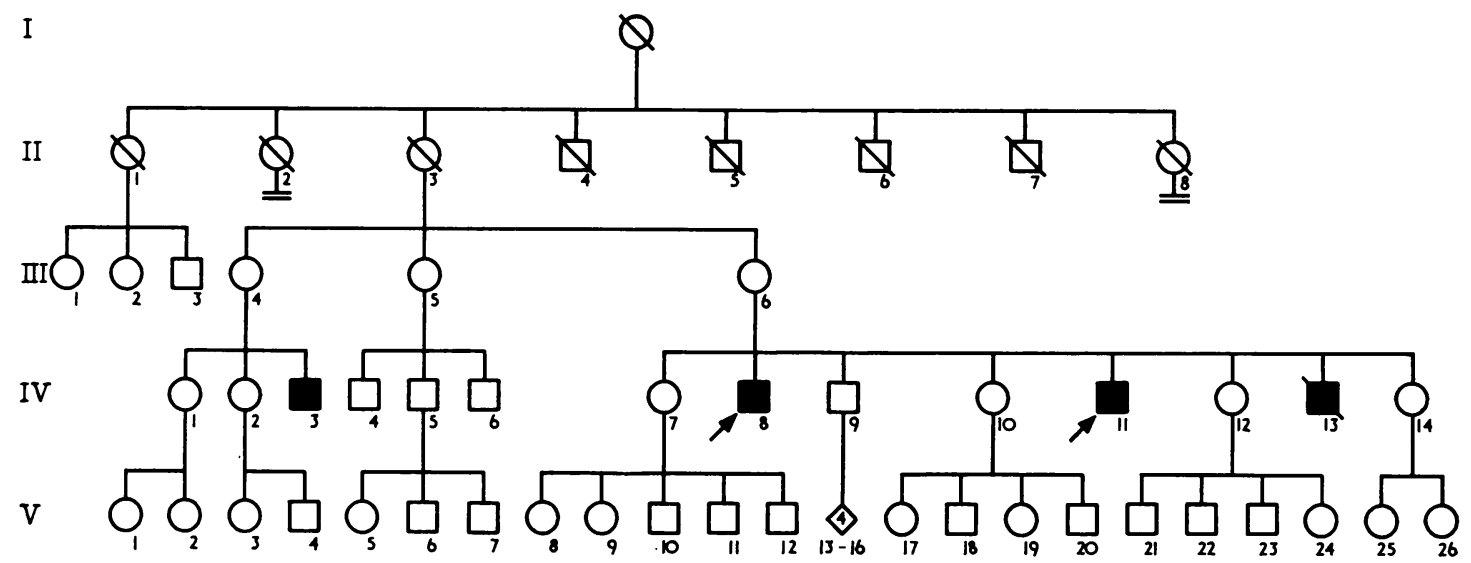

FIG. 6. Pedigree of sibship 13.

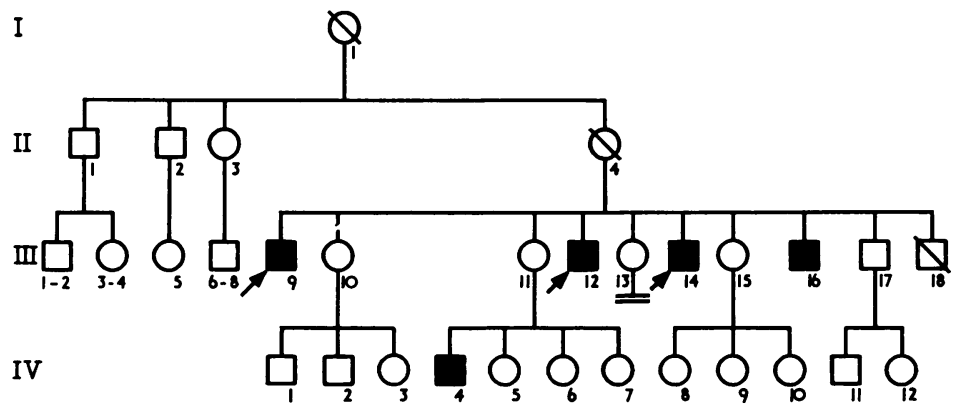

FIG. 7. Pedigree of sibship 16.

and admitted at the ages of 13 and 14. There is a history of a maternal uncle who was mentally retarded who died in an institution. He was said to have been kicked in the head by a horse at the age of 2 . There are 6 moderately mentally retarded nephews, all of whom have been physically examined and all being without physical abnormality. They are the offspring of 3 of the propositi's sisters. There is also one great nephew who is also moderately retarded without physical abnormality, although he has had fits requiring medication. Five of their relatives attend special schools and 2 are in other institutions.

\section{Sibship 16 (Fig. 7).}

The father, husband of the deceased mother (II.4), a man in his 80 s who has a had a laryngectomy, and a sister (III.10) and the wife of (III.17) were interviewed. The propositi were all admitted to PMH on the death of their mother (II.4) in childbirth. III.9 was born in 1926, admitted aged 18.

III.12 was born in 1930, admitted aged 14 . III.16 was born 1932, admitted aged 12 . III.14 was born 1931, admitted aged 13. All had done very poorly at normal school and could not read or write. III.18 died in infancy. The mother (II.4) was said to be literate. III.13 was reared in a convent on the death of her mother and has continued to work there as a domestic help. She can read but her writing is very poor. III.11 is said to be a bit slow but is protected by her husband. Her son (IV.4) is a 10-year-old boy who who attends a special school for the mentally retarded-he has not been seen but is reported to be of normal physical appearance. III.10, III.15, and III.17 were the brightest of the family and did well at school. III.17 is now the owner of a large construction firm in the city of Sydney.

Sibship 18 (Fig. 8).

A brother (II.6) of the propositi was interviewed. Details of the children of I.6 were obtained from the headmistress of the special school in the area where they lived.

II.2 and II.4 were born in 1937 and 1939 and admitted together at the age of 12 and 10 when the father deserted the family. 


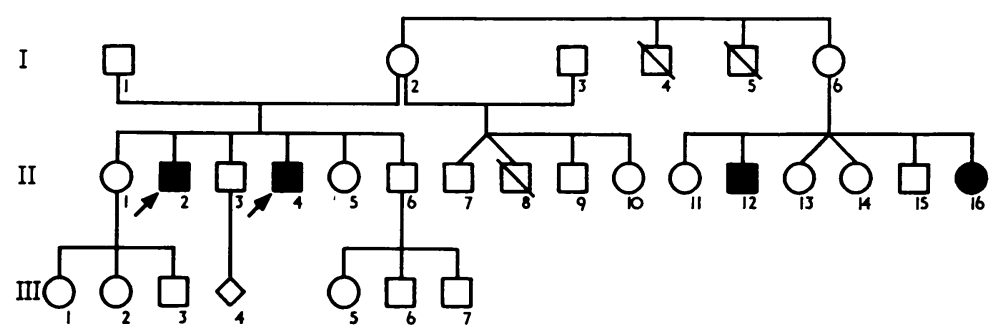

Fig. 8. Pedigree of sibship 18.

I.2, the mother of the propositi, has not been interviewed and at present is living in the country with relatives. The matron of the convalescent home where she was resident for a year described her as a simple woman of limited intelligence. Her sister (I.6) is also described as being of limited intelligence but a good mother. She lives on a property where her husband is employed as a labourer. him.

I.4 died in his teens and nothing is known about

I.5 committed suicide and is said to have been of normal intelligence.

The whereabouts of II.1, II.3, and II.5 are not known as they were brought up in foster homes following the father's desertion.

II.6, II.7, and II.9 are of normal intelligence and hold down semi-skilled jobs.
II.10 is now aged 15 and lives with her half-brother (II.6) and attends a normal school, but is doing poorly.

II.11 was born in 1948. She attended a normal school but did very poorly. She is capable of simple reading but not writing. She helps around the house and is on an invalid pension.

II.12 was born in 1950. His IQ is 30 . He attended a special school for a few years and is now described as spending his time around the house playing in the dirt. $\mathrm{He}$ is said to be of average height, of normal head circumference, and to have no epileptic fits.

II.13, II.14 and 11.15 all attend a normal school and are doing adequately.

II.16 was born in 1960 . She is probably profoundly retarded. She has repeated epileptic fits and is of short stature with a small head with spasticity of the lowe? limbs. She has always been kept at home. 